\title{
Effect of post-fermentative yeast biomass as a substitute for soybean meal on feed utilization and rumen ecology in Thai native beef cattle
}

\author{
A. Cherdthong ${ }^{1,7}$, P. Sumadong', S. Foiklang ${ }^{2}$, N. Milintawisamai ${ }^{3}$, M. Wanapat', P. Chanjula4, \\ N. Gunun ${ }^{5}$ and P. Gunun ${ }^{6}$ \\ ${ }^{1}$ Khon Kaen University, Faculty of Agriculture, Department of Animal Science, \\ Tropical Feed Resources Research and Development Center (TROFREC), Khon Kaen 40002, Thailand \\ ${ }^{2}$ Maejo University, Faculty of Animal Science and Technology, Chiangmai 50290, Thailand \\ ${ }^{3}$ KSL Green Innovation Public Company Limited, Rajathevi 10400, Bangkok, Thailand \\ ${ }^{4}$ Prince of Songkla University, Faculty of Natural Resources, Department of Animal Science, Songkhla 90112, Thailand \\ ${ }^{5}$ Udon Thani Rajabhat University, Faculty of Technology, Program in Animal Production Technology, Udon Thani 41000, Thailand \\ ${ }^{6}$ Rajamangala University of Technology-Isan, Faculty of Natural Resources, Department of Animal Science, \\ Sakon Nakhon Campus, Phangkhon 47160, Sakon Nakhon, Thailand
}

KEY WORDS: digestibility, protein sources, rumen fermentation, ruminants, yeast by-products

Received: 4 October 2018

Revised: 8 February 2019

Accepted: $\quad 31$ July 2019

${ }^{7}$ Corresponding author:

e-mail: anusornc@kku.ac.th

\begin{abstract}
The aim of this experiment was to study the influence of substituting soybean meal (SBM) with post-fermentative yeast biomass (post-FYeB) powder on feed intake, ruminal fermentation, and bacteria and protozoa content in rumen fluid in beef cattle. The study was conducted on four male Thai native beef cattle at around 1 to 2 years of age with an initial body weight (BW) of $120 \pm 20 \mathrm{~kg}$. The experimental design was a $4 \times 4$ Latin square design and the dietary treatments included four levels of SBM substitution with post-FYeB in concentrate feed: $0,33,67$ and $100 \%$. The used post-FYeB contained $26.4 \%$ crude protein. Increasing levels of post-FYeB in concentrate diets did not alter roughage intake and total intake $(P>0.05)$. Rice straw intake ranged from 2.0 to $2.1 \mathrm{~kg} \mathrm{DM} /$ day while total intake ranged from 2.7 to $2.8 \mathrm{~kg}$ DM/day. Ruminal $\mathrm{pH}$ and temperature in cattle fed various levels of post-FYeB were not significantly different among treatments. Total volatile fatty acids (VFA) and VFA profiles were not altered by different levels of post-FYeB. Post-FYeB addition into diet did not change bacteria and protozoal populations $(P>0.05)$. Thus, the inclusion of postFYeB as a replacement of SBM in ruminant diets up to $100 \%$ is suggested.
\end{abstract}

\section{Introduction}

Soybean meal (SBM) is the most important protein source used in animal rations that contains about $44 \%$ crude protein (CP) (Mukherjee et al., 2016). Nevertheless, high feed prices in Thailand and undulations in animal feed production contributed to finding alternative protein sources that could be used in ruminant diets. As a result, agroindustrial residues and waste from factories are gaining worldwide interest. Various yeast by-products have recently been commercially produced, marketed and used extensively in ruminant diets (Shurson, 2017; 2018). Polyorach and Wanapat (2015) reported that live cell yeast is a probiotic source for ruminants that can improve fermentation in the rumen and increase productive digestibility. Moreover, Robinson and Erasmus (2009) reported that yeasts affect milk 
yield and feed intake; the result is not clear, but the effect on the digestibility of the nutrients is positive. Sacharomyces cerevisiae is also used as a microorganism fermenter for bioethanol production of molasses, and the by-product after fermentation processing is called 'yeast cream waste' which contains 60-70\% yeast cells (Laluce et al., 2016; Díaz et al., 2017). This produced abundantly post-fermentative yeast biomass (post-FYeB) causes much environmental pollution, but contains many nutrients (25$30 \%$ of CP) and could be used as animal feed (Díaz et al., 2017). Therefore, utilization of post-FYeB as an alternative protein source could be beneficial in reducing feed cost and environmental pollution. However, feeding post-FYeB from bioethanol plants to ruminants has been limited. Therefore, the goal of this study was to determine the influence of substituting SBM with post-FYeB powder on feed utilization, ruminal fermentation and microorganisms in beef cattle fed low quality roughage.

\section{Material and methods}

\section{Cattle and dietary treatments}

Cattle involved in the experiment were endorsed by the Animal Ethics Committee of Khon Kaen University (Thailand), based on the Ethic of Animal Experimentation of National Research Council of Thailand.

Four male Thai native beef cattle at around 1 to 2 years of age with an initial body weight (BW) of $120 \pm 20 \mathrm{~kg}$ were used in the study. The experimental design was a $4 \times 4$ Latin square design and the dietary treatments were four levels of post-FYeB replacing SBM in concentrate diet at 0, 33, 67 and $100 \%$, respectively. Post-FYeB was obtained from bioethanol production factory of KSL Green Innovation Public Company Limited, Khon Kaen province (Thailand). Each cattle was housed in individual pen $(3 \times 5 \mathrm{~m})$ and offered concentrates (Table 1$)$ at 1\% BW twice a day at 07:00 and 16:00 with ad libitum access to rice straw feeding. The study was composed of four periods, each lasted for 21 days. During the first 14 days, all animals were fed their respective treatments, whereas during the last 7 days they were transferred to metabolism cages for total faecal collection to assess digestibility of nutrients. Feed intakes were determined separately and refusals were recorded daily. BWs were recorded at the start and end of each period. The amount of concentrate offered to the cattle was adjusted according to these measurements.

\section{Sample and analysis}

Feed offered and feed refusals of each cattle were sampled during the last 7 days of each period and weighed fresh each day before the morning feeding and oven-dried at $60{ }^{\circ} \mathrm{C}$ for 2 days. In addition, faecal samples were used to determine the feed digestion. Faecal samples were weighed and recorded daily. Five percent of the faecal voided daily were collected and stored at $-20{ }^{\circ} \mathrm{C}$ and then pooled for each cattle over the collection period. Feed samples, feed refusals and faecal samples were oven-dried at $60{ }^{\circ} \mathrm{C}$, and then successively ground in mills with 1-mm sieves. Samples were analysed for dry matter (DM), ash, $\mathrm{CP}$ and acid detergent fibre (ADF) according to an AOAC International methods (1995). Neutral detergent fibre (NDF) was determined according to Van Soest et al. (1991).

At the last day of each period, rumen fluid and jugular blood were sampled $2 \mathrm{~h}$ and $4 \mathrm{~h}$ after feeding. Rumen fluid was determined for $\mathrm{pH}$ and temperature using a portable $\mathrm{pH}$ temperature meter (HI 8424 microcomputer $\mathrm{pH}$ meter, HANNA Instruments, Woonsocket, RI, USA) and ammonia-nitrogen $\left(\mathrm{NH}_{3}-\mathrm{N}\right)$ concentration by Kjeltec Auto 1030 Analyzer (Foss Analytical A/S, Hillerød, Denmark). Rumen fluid was used for direct counts of bacteria and protozoal population using methods of Galyean (2010). Concentration of volatile fatty acids (VFA) and VFA profile were measured using high pressure liquid chromatography (HPLC) (Instruments by controller water model $600 \mathrm{E}$, water model $484 \mathrm{UV}$ detector, column novapak $\mathrm{C} 18$, column size $4 \times$ $150 \mathrm{~mm}$, mobile phase $10 \mathrm{mM} \mathrm{H}_{2} \mathrm{PO}_{4}(\mathrm{pH} 2.5$ ); ETL Testing Laboratory, Inc., Cortland, NY, USA). Blood samples were collected from a jugular vein into tubes with EDTA as anticoagulant and used for blood urea nitrogen (BUN) analysis (Crocker, 1967).

\section{Statistical analysis}

All data were subjected to analysis of variance (ANOVA) according to a $4 \times 4$ Latin square design using GLM procedure of SAS (1998). Data were analysed using the model:

$$
\mathrm{Y}_{\mathrm{ijk}}=\mu+\mathrm{M}_{\mathrm{i}}+\mathrm{A}_{\mathrm{j}}+\mathrm{P}_{\mathrm{k}}+\varepsilon_{\mathrm{ijk}}
$$

where: $Y$ - single observation, $\mu-$ overall mean, $\mathrm{M}$ - substitution levels $(\mathrm{i}=1,2,3,4), \mathrm{A}$ - effect of cattle $(\mathrm{j}=1,2,3,4), \mathrm{P}$ - period $(\mathrm{k}=1,2,3,4)$ and $\varepsilon$ - residual effect. The results are presented as mean values and standard error of the means. Means were compared using Duncan's multiple range test (Steel and Torrie, 1980). Significance was declared at $P<0.05$ as representing statistically significant differences. 


\section{Results and discussion}

Chemical composition of the diets. The $\mathrm{CP}$ content of post-FYeB in the current study was $26.4 \%$ (Table 1) which was only lower than yeast cells of brewer's yeast (46.5\% of CP; Sauvant et al., 2004). Post-FYeB contains high ash content that could have an effect on digestibility, however, in the present study the post-FYeB was included in only $10 \% \mathrm{DM}$ of concentrate diets $(3.04 \%$ ash). The animals received $1.3 \mathrm{~kg} / \mathrm{head} /$ day concentrates and ash intake was only $0.0395 \% \mathrm{DM}$, thus the ash content in post-FYeB has no adverse effect on digestibility. Using post-FYeB to replace SBM in ruminant diets gives an opportunity not only to use post-FYeB resourcefully, but also to lead beneficial metabolic alters in cattle. Post-FYeB or yeast cream is generated from bioethanol production and contains about $60-70 \%$ of yeast cells, thus inclusion of post-FYeB into concentrate diet may provide an additional source of protein and essential amino acids to animals (Díaz et al., 2017).

The control group diet included $10 \mathrm{~kg}$ DM of SBM, whereas the experimental group was given 3.3 to $10 \mathrm{~kg} \mathrm{DM}$ of post-FYeB as a replacement of SBM and urea was used as N source to balance isonitrogenous content. The urea was additionally

Table 1. Ingredients and chemical composition of experimental diets

\begin{tabular}{|c|c|c|c|c|c|}
\hline \multirow{2}{*}{ Indices } & \multicolumn{4}{|c|}{ Level of post-FYeB, \% } & \multirow{2}{*}{$\begin{array}{l}\text { Rice Post- } \\
\text { straw FYeB }\end{array}$} \\
\hline & 0 & 33 & 67 & 100 & \\
\hline \multicolumn{6}{|l|}{ Ingredients, kg DM } \\
\hline cassava chips & 56.0 & 56.0 & 56.0 & 56.0 & \\
\hline soybean meal & 10.0 & 6.7 & 3.3 & 0.0 & \\
\hline post-FYeB & 0.0 & 3.3 & 6.7 & 10.0 & \\
\hline rice bran & 14.5 & 14.5 & 14.5 & 14.5 & \\
\hline coconut meal & 7.0 & 7.0 & 7.0 & 7.0 & \\
\hline palm kernel meal & 7.0 & 7.0 & 7.0 & 7.0 & \\
\hline urea & 1.5 & 1.7 & 1.9 & 2.1 & \\
\hline pure sulphur & 1.0 & 1.0 & 1.0 & 1.0 & \\
\hline mineral premix ${ }^{1}$ & 1.0 & 1.0 & 1.0 & 1.0 & \\
\hline molasses, liquid & 1.0 & 1.0 & 1.0 & 1.0 & \\
\hline salt & 1.0 & 1.0 & 1.0 & 1.0 & \\
\hline \multicolumn{6}{|c|}{ Chemical composition, \% DM } \\
\hline $\mathrm{DM}, \%$ & 91.4 & 92.1 & 91.8 & 92.0 & 95.995 .0 \\
\hline organic matter & 87.1 & 87.3 & 87.3 & 87.4 & 88.669 .6 \\
\hline ash & 12.9 & 12.7 & 12.7 & 12.6 & 11.430 .4 \\
\hline crude protein & 13.6 & 13.7 & 13.7 & 14.0 & 2.826 .4 \\
\hline $\begin{array}{l}\text { neutral detergent } \\
\text { fibre }\end{array}$ & 73.2 & 72.5 & 71.9 & 71.5 & 78.98 .2 \\
\hline acid detergent fibre & 55.4 & 53.1 & 52.7 & 52.6 & 58.44 .6 \\
\hline
\end{tabular}

post-FYeB - post-fermentative yeast biomass; DM - dry matter; ${ }^{1}$ minerals and vitamins (each $\mathrm{kg}$ contained): IU: vit. A 10000000 , vit. E 70 000, vit. D 1600 000; g: Fe 50, Zn 40, Mn 40, Co 0.1, Cu 10, Se $0.1,10.5$ increased from 0.1 to $0.6 \mathrm{~kg} \mathrm{DM}$ when compared to the control group $(1.5 \mathrm{~kg} \mathrm{DM})$. This could be due to low CP in post-FYeB in comparison to SBM. Utilization of urea as a non-protein $\mathrm{N}$ substitution is attractive in cattle feeds, because of its lower price than that of SBM and its high degradability in the rumen (Cherdthong et al., 2014). Urea is changed via rumen $\mathrm{NH}_{3}-\mathrm{N}$ into microbial mass, thus supplying supplementary microbial protein to the ruminant (Cherdthong and Wanapat, 2010). The concentrates contained about 13.6 to $14.0 \%$ CP that was fed to meet protein requirements for tropical beef cattle.

Feed intake and digestibility. Effects of postFYeB as a replacement for SBM on feed intake are shown in Table 2. Increasing level of post-FYeB in concentrate from 0 to $100 \%$ as the replacement of SBM did not alter roughage intake and total intake. Rice straw intake ranged from 2.0 to $2.1 \mathrm{~kg} \mathrm{DM} /$ day and from 1.6 to $1.7 \%$ of BW while total intake ranged from 3.3 to $3.4 \mathrm{~kg} \mathrm{DM} /$ day and from 2.6 to $2.7 \%$ of $\mathrm{BW}$, which were in the normal range for Thai native beef cattle. However, Shurson (2018) has shown that the supplementation of live yeast may generally enhance roughage digestibility. These results indicated that post-FYeB could substitute SBM with no adverse effects on feed intake

Table 2. Effect of substitution of soybean meal (SBM) by postfermentative yeast biomass (post-FYeB) on feed intake, nutrients intake and digestibility in Thai native beef cattle

\begin{tabular}{|c|c|c|c|c|c|c|}
\hline \multirow{2}{*}{ Indices } & \multicolumn{4}{|c|}{ Replacing SBM with post-FYeB, \% } & \multirow{2}{*}{ SEM } & \multirow{2}{*}{$\begin{array}{l}P \text { - } \\
\text { value }\end{array}$} \\
\hline & 0 & 33 & 67 & 100 & & \\
\hline \multicolumn{7}{|l|}{ Concentrate intake } \\
\hline kg DM/day & 1.3 & 1.3 & 1.3 & 1.3 & 0.01 & ns \\
\hline$\%$ of body weight (BW) & 1.0 & 1.0 & 1.0 & 1.0 & 0.01 & ns \\
\hline \multicolumn{7}{|l|}{ Rice straw intake } \\
\hline $\mathrm{kg} \mathrm{DM} /$ day & 2.0 & 2.0 & 2.1 & 2.0 & 0.02 & ns \\
\hline$\%$ of $\mathrm{BW}$ & 1.6 & 1.6 & 1.7 & 1.6 & 0.02 & ns \\
\hline \multicolumn{7}{|l|}{ Total intake } \\
\hline $\mathrm{kg} \mathrm{DM} / \mathrm{day}$ & 3.3 & 3.3 & 3.4 & 3.3 & 0.04 & ns \\
\hline$\%$ of BW & 2.6 & 2.6 & 2.7 & 2.6 & 0.04 & ns \\
\hline \multicolumn{7}{|l|}{ Nutrients intake, $\mathrm{kg} / \mathrm{day}$} \\
\hline organic matter & 2.87 & 2.87 & 2.91 & 2.87 & 0.03 & ns \\
\hline crude protein & 0.21 & 0.21 & 0.20 & 0.22 & 0.01 & ns \\
\hline neutral detergent fibre & 2.40 & 2.38 & 2.41 & 2.37 & 0.03 & ns \\
\hline acid detergent fibre & 1.83 & 1.83 & 1.82 & 1.79 & 0.02 & ns \\
\hline \multicolumn{7}{|c|}{ Nutrients digestibility, \% DM } \\
\hline DM, \% & 67.2 & 65.9 & 66.9 & 71.1 & 1.05 & ns \\
\hline organic matter & 71.8 & 70.6 & 71.3 & 71.7 & 0.39 & ns \\
\hline crude protein & 72.8 & 74.7 & 73.3 & 74.3 & 0.59 & ns \\
\hline neutral detergent fibre & 69.4 & 72.8 & 71.9 & 68.2 & 2.59 & ns \\
\hline acid detergent fibre & 57.0 & 57.7 & 59.1 & 58.2 & 0.87 & ns \\
\hline
\end{tabular}

DM - dry matter; SEM - standard error of means; ns - non-significant 
in beef cattle. Similarly, Cherdthong et al. (2014) revealed that using residue from slaughterhouses to replace SBM did not alter feed intake, which ranged from 2.8 to $3.0 \mathrm{~kg} /$ day. Moreover, organic matter (OM), CP, NDF and ADF intakes were similar among diets $(P>0.05)$. In Table 2 data of nutrient digestibility in animals fed different levels of post-FYeB that replaced SBM is also presented. The results show that the nutrient digestibilities of DM, $\mathrm{OM}, \mathrm{CP}, \mathrm{NDF}$, and ADF in cattle fed various levels of post-FYeB were not significantly different among diets $(P>0.05)$. However, the numerical improvement on $\mathrm{CP}$ digestibility for $100 \%$ post-FYeB was higher than that of the $100 \%$ SBM group $(1.5 \% \mathrm{DM})$, which could be possibly due to the fact that $\mathrm{CP}$ of the yeast biomass is easier fermented by bacteria than that of SBM (Díaz et al., 2017). In addition, adding urea to the SBM replacement may also increase CP digestibility (Cherdthong and Wanapat, 2010). Thus, it was indicated that post-FYeB can replace $100 \%$ of the SBM content as a protein source in concentrate diets with no adverse effect on digestibility.

Rumen ecology and microorganisms. Rumen ecology and microorganisms in animals fed different levels of post-FYeB as a replacement of SBM are presented in Table 3. Rumen $\mathrm{pH}$ and rumen temperature in cattle fed various levels of post-FYeB were not significantly different among diets. The rumen $\mathrm{pH}$ at 0 and $4 \mathrm{~h}$ post feeding ranged from 6.6 to 6.8 and from 6.6 to 6.7 , respectively. In addition, ruminal temperatures at 0 and $4 \mathrm{~h}$ post feeding ranged from from 38.3 to $38.7{ }^{\circ} \mathrm{C}$ and from 38.4 to $38.9{ }^{\circ} \mathrm{C}$, respectively. Similarly, Polyorach and Wanapat (2015) also reported that supplementation ofyeast into diets resulted in rumen $\mathrm{pH}$ between 6.5 and 7.0 , and temperature from 38 to $39^{\circ} \mathrm{C}$, which are considered normal and suitable for microbial activity in the rumen. Replacing SBM with post-FYeB did not change bacterial and protozoal populations $(P>0.05)$. At 0 and $4 \mathrm{~h}$ post feeding, the bacterial population ranged from 3.1 to $3.8 \times 10^{10} \mathrm{cells} / \mathrm{ml}$ and from 2.9 to $4.1 \times 10^{10}$ cells $/ \mathrm{ml}$, respectively, while the protozoal population ranged from 4.0 to $4.5 \times$ $10^{6}$ cells $/ \mathrm{ml}$ and from 3.9 to $4.1 \times 10^{6}$ cells $/ \mathrm{ml}$, respectively. It was revealed that post-FYeB did not contain antibacterial substances and did not show a negative effect on concentration of bacteria and protozoa in the rumen of beef cattle. However, Pérez Quintana et al. (2016) reported that yeasts can supply essential growth factors (e.g., peptides, amino acids, $\beta$-glucan, sugar, etc.) for some rumen microorganisms. Díaz et al. (2017) also confirmed the idea that yeast hydrolysate supplementation
Table 3. Rumen ecology, bacteria and protozoa content in rumen fluid, and blood urea nitrogen level in Thai native beef cattle fed different levels of post-fermentative yeast biomass (post-FYeB) substituting soybean meal (SBM)

\begin{tabular}{|c|c|c|c|c|c|c|}
\hline \multirow{2}{*}{ Indices } & \multicolumn{4}{|c|}{ Replacing SBM with post-FYeB, $\%$} & \multirow{2}{*}{ SEM } & \multirow{2}{*}{$P$-value } \\
\hline & 0 & 33 & 67 & 100 & & \\
\hline \multicolumn{7}{|l|}{ Ruminal pH } \\
\hline $\mathrm{O} \mathrm{h}$ post feeding & 6.6 & 6.8 & 6.8 & 6.6 & 0.07 & ns \\
\hline $4 \mathrm{~h}$ post feeding & 6.6 & 6.6 & 6.7 & 6.6 & 0.07 & ns \\
\hline \multicolumn{7}{|c|}{ Ruminal temperature, ${ }^{\circ} \mathrm{C}$} \\
\hline $0 \mathrm{~h}$ post feeding & 38.3 & 38.5 & 38.7 & 38.4 & 0.17 & ns \\
\hline $4 \mathrm{~h}$ post feeding & 38.4 & 38.9 & 38.8 & 38.7 & 0.12 & ns \\
\hline \multicolumn{7}{|l|}{$\mathrm{NH}_{3}-\mathrm{N}, \mathrm{mg} / \mathrm{dl}$} \\
\hline $\mathrm{O} \mathrm{h}$ post feeding & 12.3 & 12.2 & 12.1 & 12.0 & 0.33 & ns \\
\hline $4 \mathrm{~h}$ post feeding & 15.2 & 15.0 & 14.8 & 14.7 & 0.49 & ns \\
\hline \multicolumn{7}{|c|}{ Bacteria, $\times 10^{10} \mathrm{cells} / \mathrm{ml}$} \\
\hline $\mathrm{O} \mathrm{h}$ post feeding & 3.5 & 3.1 & 3.8 & 3.8 & 0.30 & ns \\
\hline $4 \mathrm{~h}$ post feeding & 2.9 & 4.1 & 3.4 & 2.2 & 0.79 & ns \\
\hline \multicolumn{7}{|c|}{ Protozoa, $\times 10^{6} \mathrm{cells} / \mathrm{ml}$} \\
\hline $0 \mathrm{~h}$ post feeding & 4.2 & 4.5 & 4.2 & 4.0 & 0.02 & ns \\
\hline $4 \mathrm{~h}$ post feeding & 4.1 & 4.0 & 3.9 & 4.0 & 0.10 & ns \\
\hline \multicolumn{7}{|l|}{ BUN, mg/dl } \\
\hline $0 \mathrm{~h}$ post feeding & 11.0 & 9.0 & 10.5 & 11.5 & 0.91 & ns \\
\hline $4 \mathrm{~h}$ post feeding & 13.3 & 12.3 & 13.8 & 13.8 & 0.75 & ns \\
\hline
\end{tabular}

SEM - standard error of means; ns - non-significant; BUN - blood urea nitrogen

tends to enhance microorganism growth in the liquid phase when compared to non-supplemented group. A stimulation of the ruminal microbes growth by live and dead yeast has been shown in some studies (Miller-Webster et al., 2002; Kettunen et al., 2016), but current results did not confirm them. Concentration of ruminal $\mathrm{NH}_{3}-\mathrm{N}$ ranged from 12.0 to $15.2 \mathrm{mg} / \mathrm{dl}$, which is similar to those previously revealed by Wanapat and Pimpa (1999), who stated that this range was reasonable for improving ruminal fermentation and microorganism activity. Rumen $\mathrm{NH}_{3}-\mathrm{N}$ content is a crude predictor of efficiency of dietary $\mathrm{N}$ transformation into microbial protein (Firkins et al., 2007; Broderick and Muck 2009).

The data for blood urea nitrogen (BUN) in animals fed various levels of post-FYeB in concentrate diets is also shown in Table 3. BUN in cattle fed various levels of post-FYeB was not significantly different among groups $(P>0.05)$. BUN at 0 and $4 \mathrm{~h}$ post feeding were ranged from 9.0 to $11.5 \mathrm{mg} / \mathrm{dl}$ and from 12.3 to $13.8 \mathrm{mg} / \mathrm{dl}$, respectively. Wanapat (1990) reported that BUN concentrations ranged from 6.3 to $25.5 \mathrm{mg} / \mathrm{dl}$, depending on feeding regimes. Therefore, post-FYeB can replace SBM in the concentrate diet with no adverse effect on urea-nitrogen concentration in the blood stream. 
Volatile fatty acid (VFA) concentration. VFA concentration data in animals fed various levels of post-FYeB as a substitute for SBM in diets is presented in Table 4. The VFA concentration depends on the proportion of feeding, according to Wanapat (1990), who reported the optimum concentrations of fatty acids that evaporated easily in the rumen that were: acetic acid (C2) of about $65-70 \%$, as well as $20-25 \%$ propionic acid (C3) and $10-15 \%$ butyric acid (C4). Total VFA, C2, C4 and C3 as well as $\mathrm{C} 2: \mathrm{C} 3$ ratio in cattle fed various levels of postFYeB were not significantly different among diets $(P>0.05)$. Total VFA at 0 and $4 \mathrm{~h}$ post feeding ranged from 118.4 to $118.6 \mathrm{mmol} / \mathrm{l}$ and from 118.5 to $118.7 \mathrm{mmol} / \mathrm{l}$, respectively. However, some studies revealed that supplementation with yeast hydrolysate shifted the VFA profile from $\mathrm{C} 2$ to $\mathrm{C} 3$ and reduced the $\mathrm{C} 2$ : $\mathrm{C} 3$ ratio in batch cultures (Kettunen et al., 2016) and Rusitec fermenters (Oeztuerk et al., 2016; Díaz et al., 2017).

Table 4. Volatile fatty acid (VFA) concentration in Thai native beef cattle fed different levels of post-fermentative yeast biomass (postFYeB) substituting soybean meal (SBM)

\begin{tabular}{|c|c|c|c|c|c|c|}
\hline \multirow{2}{*}{ Indices } & \multicolumn{4}{|c|}{ Replacing SBM with post-FYeB, \% } & \multirow{2}{*}{ SEM } & \multirow{2}{*}{$P$-value } \\
\hline & 0 & 33 & 67 & 100 & & \\
\hline \multicolumn{7}{|l|}{ Total VFA, mmol/l } \\
\hline $0 \mathrm{~h}$ post feeding & 118.6 & 118.6 & 118.5 & 118.4 & 0.05 & ns \\
\hline $4 \mathrm{~h}$ post feeding & 118.7 & 118.5 & 118.6 & 118.5 & 0.13 & ns \\
\hline \multicolumn{7}{|l|}{ Acetate (C2), \% } \\
\hline $0 \mathrm{~h}$ post feeding & 64.2 & 63.1 & 63.8 & 62.8 & 0.87 & ns \\
\hline $4 \mathrm{~h}$ post feeding & 64.1 & 63.7 & 63.5 & 63.5 & 1.21 & ns \\
\hline \multicolumn{7}{|l|}{ Propionate (C3), \% } \\
\hline $0 \mathrm{~h}$ post feeding & 24.7 & 25.8 & 25.2 & 25.8 & 0.56 & ns \\
\hline $4 \mathrm{~h}$ post feeding & 23.9 & 24.9 & 25.1 & 25.5 & 1.23 & ns \\
\hline \multicolumn{7}{|l|}{ Butyrate (C4), \% } \\
\hline $0 \mathrm{~h}$ post feeding & 11.3 & 11.1 & 10.9 & 11.2 & 0.59 & ns \\
\hline $4 \mathrm{~h}$ post feeding & 11.9 & 11.3 & 11.4 & 10.9 & 0.29 & ns \\
\hline \multicolumn{7}{|l|}{$\mathrm{C} 2: \mathrm{C} 3$ ratio } \\
\hline $0 \mathrm{~h}$ post feeding & 2.6 & 2.5 & 2.6 & 2.4 & 0.09 & ns \\
\hline $4 \mathrm{~h}$ post feeding & 2.7 & 2.6 & 2.6 & 2.5 & 0.17 & ns \\
\hline
\end{tabular}

SEM - standard error of means; ns - non-significant

\section{Conclusions}

The substitution of soybean meal (SBM) by post-fermentative yeast biomass (post-FYeB) in diet could be a practical alternative for cattle. The replacement of SBM by post-FYeB up to $100 \%$ in cattle feed is suggested. However, future studies on the effect of post-FYeB as a substitute for SBM should be elucidated under the production trial.

\section{Acknowledgments}

The authors would like to express our sincere thanks to the KSL Green Innovation Public Company Limited, Thailand and Increase Production Efficiency and Meat Quality of Native Beef and Buffalo Research Group, KhonKaen University (KKU) for providing financial support for the research and the use of research facilities. This work were also supported by Research and Researcher for Industry (RRi), the Thailand Research Fund (TRF) contract grant PHD60I0015 and TFR-IRG5980010. The Post-Doctoral Training Program from Research Affairs and Graduate School, Khon Kaen University, Thailand. (Grant no. 58440) is also acknowledged.

\section{References}

AOAC International, 1995. Official Methods of Analysis of AOAC International. $16^{\text {th }}$ Edition. Arlington, VA (USA)

Broderick G.A., Muck R.E., 2009. Effect of alfalfa silage storage structure and rumen-protected methionine on production in lactating dairy cows. J. Dairy Sci. 92, 1281-1289, https://doi. org/10.3168/JDS.2008-1303

Cherdthong A., Wanapat M., 2010. Development of urea products as rumen slow-release feed on ruminant production: A review. Aust. J. Basic Appl. Sci. 4, 2232-2241

Cherdthong A., Wanapat M., Saenkamsorn A., Waraphila N., Khota W., Rakwongrit D., Anantasook N., Gunun P., 2014. Effects of replacing soybean meal with dried rumen digesta on feed intake, digestibility of nutrients, rumen fermentation and nitrogen use efficiency in Thai cattle fed on rice straw. Livest. Sci. 169, 71-77, https://doi.org/10.1016/j.livsci.2014.09.008

Crocker C.L., 1967. Rapid determination of urea nitrogen in serum or plasma without deproteinization. Am. J. Med. Technol. 33, 361-365

Díaz A., Ranilla M.J., Saro C., Tejido M.L., Pérez-Quintana M., Carro M.D., 2017. Influence of increasing doses of a yeast hydrolyzate obtained from sugarcane processing on in vitro rumen fermentation of two different diets and bacterial diversity in batch cultures and Rusitec fermenters. Anim. Feed Sci. Technol. 232, 129-138, https://doi.org/10.1016/j.anifeedsci.2017.08.011

Firkins J.L., Yu Z., Morrison M., 2007. Ruminal nitrogen metabolism: perspectives for integration of microbiology and nutrient for dairy. J. Dairy Sci. 90, Suppl., E1-E16, https://doi. org/10.3168/jds.2006-518

Galyean M.L., 2010. Laboratory Procedures in Animal Nutrition Research. Revised Edition. Department of Animal and Food Science. Texas Tech University. Lubbock, TX (USA)

Kettunen H., Vuorenmaa J., Gaffney D., Apajalahti J., 2016. Yeast hydrolysate product enhances ruminal fermentation in vitro. J. Appl. Anim. Nutr. 4, e1, https://doi.org/10.1017/jan.2015.14

Laluce C., Leite G.R., Zavitoski B.Z., Zamai T.T., Ventura R., 2016. Fermentation of sugarcane juice and molasses for ethanol production. In: I.M. O'Hara, S.G. Mundree (Editors). Sugarcane-Based Biofuels and Bioproducts. John Willey \& Sons. Hoboken, NY (USA), https://doi. org/10.1002/9781118719862.ch3 
Miller-Webster T., Hoover W.H., Holt M., Nocek J.E., 2002. Influence of yeast culture on ruminal microbial metabolism in continuous culture. J. Dairy Sci. 85, 2009-2014, https://doi.org/10.3168/ jds.S0022-0302(02)74277-X

Mukherjee R., Chakraborty R., Dutta A., 2016. Role of fermentation in improving nutritional quality of soybean meal - a review. Asian-Australas. J. Anim. Sci. 29, 1523-1529, https://doi. org/10.5713/ajas.15.0627

Oeztuerk H., Emre B., Breves G., 2016. Effects of hydrolysed yeasts on ruminal fermentation in the rumen simulation technique (Rusitec). Vet. Med. 61, 195-203, https://doi. org/10.17221/8820-VETMED

Pérez Quintana M., Milian Florido G., Bocourt Salabarría R., Alemán Pérez R., 2016. In vitro evaluation of prebiotics in hydrolysates of yeast (Saccharomyces cerevisiae) prepared by different methods. Cien. Vida 16, 64-75, https://doi.org/10.33936/ la_tecnica.v0i16.537

Polyorach S., Wanapat M., 2015. Potential of yeast as probiotics in ruminants. Khon Kaen Agric. J. 43, 191-206

Robinson P.H., Erasmus L.J., 2009. Effects of analyzable diet components on responses of lactating dairy cows to Saccharomyces cerevisiae based yeast products: Asystematic review of the literature. Anim. Feed Sci. Technol. 149, 185-198, https://doi.org/10.1016/j.anifeedsci.2008.10.003

SAS, 1998. User's Guide: Statistics. Version 6. SAS Institute Inc. Cary, NC (USA)
Sauvant D., Perez J.-M., Tran G. (Editors), 2004. Tables of Composition and Nutritional Value of Feed Materials. $2^{\text {nd }}$ Revised Edition. Wageningen Academic Publishers. Wageningen (The Netherlands), https://doi.org/10.3920/978-90-8686-668-7

Shurson G.C., 2018. Yeast and yeast derivatives in feed additives and ingredients: Sources, characteristics, animal responses, and quantification methods. Anim. Feed Sci. Technol. 235, 60-76, https://doi.org/10.1016/j.anifeedsci.2017.11.010

Shurson G.C., 2017. The role of biofuels coproducts in feeding the world sustainably. Ann. Rev. Anim. Biosci. 5, 229-254, https:// doi.org/10.1146/annurev-animal-022516-022907

Steel R.G.D., Torrie J.H., 1980. Analysis of covariance. In: Principles and Procedures of Statistics: a Biometrical Approach. $2^{\text {nd }}$ Edition. McGraw-Hill. New York, NY (USA)

Van Soest P.J., Robertson J.B., Lewis B.A., 1991. Methods for dietary fiber neutral detergent fiber, and nonstarch polysaccharides in relation to animal nutrition. J. Dairy Sci. 74, 3583-3597, https://doi.org/10.3168/jds.S0022-0302(91)78551-2

Wanapat M., 1990. Nutritional Aspects of Ruminant Production in Southeast Asia with Special Reference to Thailand. Khon Kaen University. Khon Kaen (Thailand)

Wanapat M., Pimpa O., 1999. Effect of ruminal $\mathrm{NH}_{3}-\mathrm{N}$ levels ruminal fermentation, purine derivatives, digestibility and rice straw intake in swamp buffaloes. Asian-Australas. J. Anim. Sci. 12, 904-907, https://doi.org/10.5713/ajas.1999.904 